\title{
LEPROSY IN GAMBIA. WEST AFRICA
}

JAMES A. MCFADZEAN, M.D.

National Institute for Medical Research, London, and

JoHN F. McCourT, M.B., D.P.H. Medical Officer of Health, Gambia.

From the Medical Research Council Laboratories and the Medical Department, Gambia.

This paper gives the results of a survey of leprosy in Gambia which was conducted at the same time as a survey of the forms of treponematoses occurring in the country.

Gambia lies between $13^{\prime}$ and $14^{\prime}$ North, and is a narrow strip of territory approximately ro miles wide on either side of the river Gambia, and extending inland to the East for some 300 miles. The greater part of the country is a British Protectorate which is divided into four approximately equal Divisions, with a total population of 26r,564 (Protectorate Census, I953). There are five main tribes in Gambia, namely the Mandinkos, the Wollofs, the Fulas, the Serahulis, and the Jolas. One village of each of the predominant tribes in each Division of the Protectorate was surveyed. In three of the Divisions, there were four important tribes, and in the fourth Division there were three, i.e. a total of fifteen villages was surveyed. An attempt was made to obtain villages of approximately 400-500 inhabitants (a large village by Gambia standards), but where this was not possible, small neighbouring villages were grouped together. Villages were chosen where at least 90 per cent of the inhabitants belonged to the same tribe, to see if there was any difference in the incidence of leprosy among the tribes. The total number of people examined was 5,890:

\section{METHODS}

In each village visited, an examination tent was set up, or a roofless enclosure built for us by the villagers. Every effort was made to see all the inhabitants of the village. The entire skin of the body of each person was examined, and the major nerves 
palpated. Cases of leprosy and suspected cases were examined jointly. Owing to time and transport difficulties, skin smears were not made, and the classification of cases rested purely on clinical grounds. The classification employed was the simplest, and consisted of lepromatous cases, tuberculoid cases and cases of doubtful classification. In the absence of skin smears, errors must have arisen here, but an overall picture of the disease in Gambia has been obtained.

In some villages, the people were afraid that we were going to remove the cases of leprosy from the village, and it sometimes took a lot of explaining before they agreed to come to the examination tent. In other villages, we apparently made a greater impression on the local populace, as cases of leprosy were brought to us from the surrounding villages, but every attempt was made to exclude these. In one village we met the local witch-doctor who was very friendly and regarded us as colleagues. $\mathrm{He}$ had three people in his compound with leprosy who were undergoing treatment, but they were not included in the survey figures as they had come to the village during the last year from some considerable distance away. In Upper River Division, we were greatly assisted by an anthropologist who knew the people in the villages intimately, but in the other Divisions some of the villagers may have eluded us. There is no claim to roo per cent accuracy in the results obtained, and the incidence of leprosy which we have recorded is, if anything, lower than the true figures.

\section{RESULTS}

The map shows the villages surveyed with the predominant tribe for each village in brackets. The villages are fairly well distributed over the Protectorate.

The incidences of leprosy found are shown in Table I. The incidence in the different villages varied from $\mathrm{I} \%$ to $3.9 \%$, and the incidence in the different Divisions from $1.4 \%$ to $3.1 \%$. The overall figure for the Protectorate was $2.4 \%$. This means that there are approximately 6,000 people in the Protectorate who have leprosy.

The incidence of the different clinical types of leprosy is recorded in Table 2. This shows that $26.6 \%$ of the cases were clinically infectious, i.e. there are approximately $I, 500$ cases of infectious leprosy in the Protectorate. 


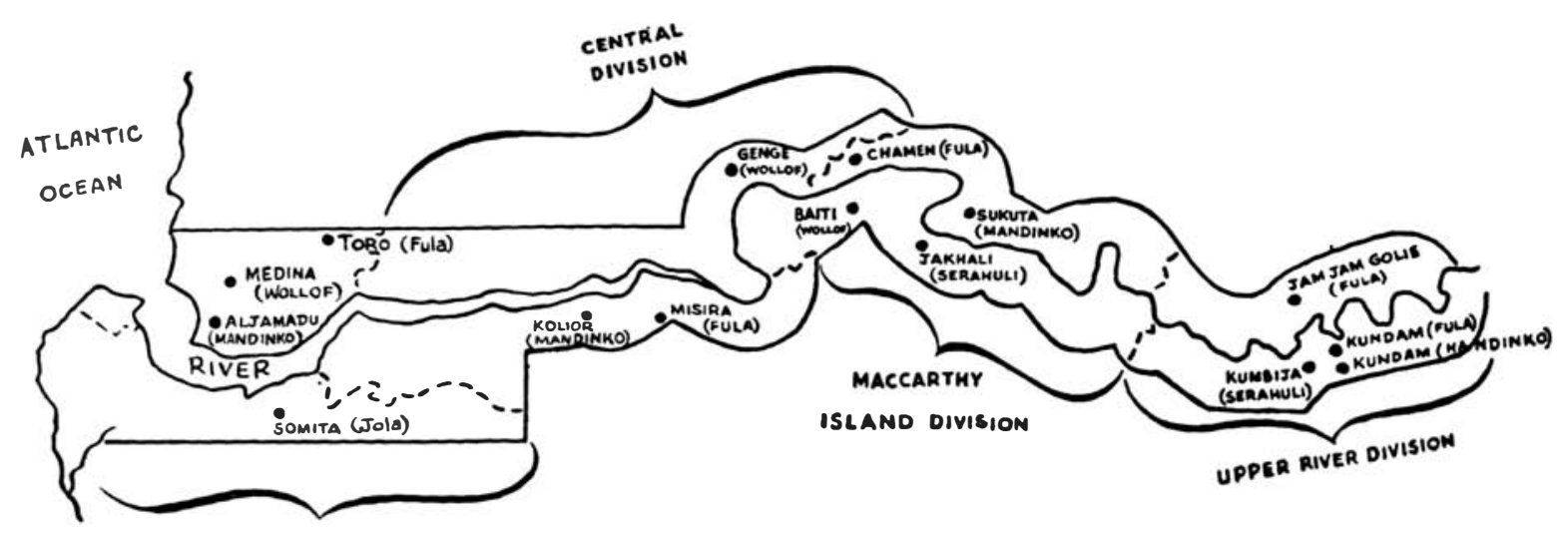

WESTERN DIVISION

Showing the villages surveyed with the name of the tribe in brackets 
The incidence of leprosy found among the different tribes was as follows:-

$\begin{array}{lllll}\text { Wollof ... } & \ldots & \ldots & \ldots & 2.8 \% \\ \text { Serahuli } & \ldots & \ldots & \ldots & 2.5 \% \\ \text { Fula } \ldots & \ldots & \ldots & \ldots & 2.4 \% \\ \text { Jola } \ldots & \ldots & \ldots & \ldots & 2.1 \% \\ \text { Mandinko } & \ldots & \ldots & \ldots & 1.9 \%\end{array}$

Analysis of the above figures showed no statistically significant differences in the tribal incidence of the disease.

The incidence in males was $2.5 \%$ and the incidence in females $2.2 \%$. There is no statistically significant difference between these two figures.

The graph shows the distribution in age groups of the cases of leprosy seen. It also shows the percentage of each age group who were found to have leprosy. Most of the cases of leprosy were between the ages of 6 and 30 years, but the percentage incidence in each age group was remarkably consistent after the first five years of life.

A number of people were seen who have enlargement of one or more of the major nerves without skin signs of leprosy. These were not included in the results as cases of leprosy, but it is likely that these people did in fact have the disease. Ross (I947) stated that in Gambia he found a number of cases of leprosy where the main clinical signs were nerve enlargement with only vague visible cutaneous signs. Lowe (personal communication) has also seen cases in India where nerve enlargement was the only obvious clinical manifestation of the disease.

\section{Discussion}

There is very little stigma attached to leprosy in Gambia. Occasionally the Health Department in the main town of Bathurst receives a request for the removal of a person with leprosy from a compound, and leprosy is also used in Gambia as grounds for divorce under Muslim law. There is little attempt at segregation among the people themselves. Occasionally two or three people with leprosy live together, but they are not isolated from village activities. More often, however, the people with leprosy continue to lead a normal life until they are grossly mutilated by the disease. The people are aware of the infectious nature of certain diseases including leprosy, but they show no fear of living in association with leprosy. This is in sharp contrast to Eastern Nigeria where the people are very leprosy conscious and at the first sign of the disease the patient is sent off for examination and treatment. 
Ross (1947) surveyed three out of the four Divisions of the Protectorate of Gambia. He reported the incidence of leprosy to be $2.5 \%$. Our figure of $2.4 \%$ for spot surveys in the four

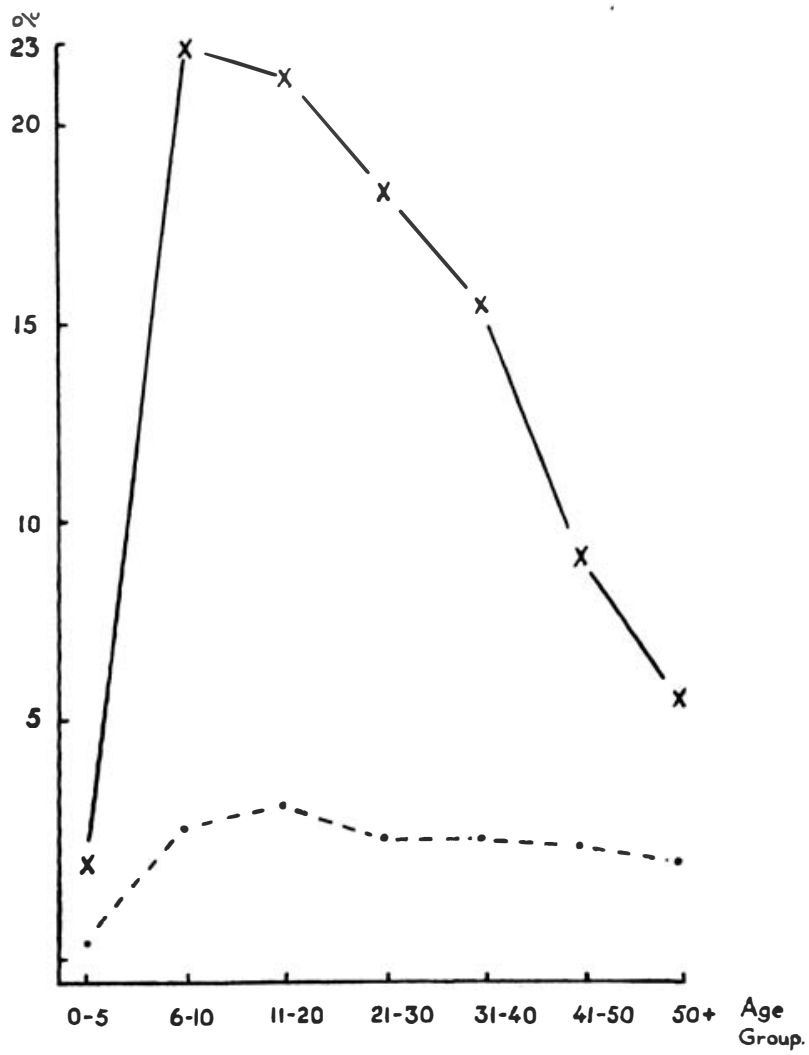

Showing the distribution in age groups of the cases of leprosy seen and the percentage incidence of leprosy in each age group.

Divisions is very close to this indeed. Ross recorded that the further up river one went, the higher was the incidence of leprosy. We found this to be the case in the three upper river Divisions, but recorded the second highest incidence in the most Westerly Division.

The different incidences recorded among the different tribes were not statistically significant. It is possible that larger samples might have revealed significant differences.

The incidence of leprosy in Gambia is high, and warrants urgent attention. Until recently, the Gambians did not believe that there was any cure for the disease. However, in the past months a number of cases have been receiving treatment with Dapsone, and owing to the rapid response of tuberculoid cases 
the attendance figures for twice weekly treatment have been good. A difficulty which will be encountered in the control of leprosy in Gambia will be the isolation of infectious cases. Voluntary isolation if introduced at present will meet with little success, and only by education will the people realise the value and necessity of this measure. Compulsory isolation is of course out of the question.

The possibility of trying B.C.G. in the control of leprosy in Gambia should be borne in mind. Gambia is a small country, where few measures have been taken against leprosy, where there is a high incidence of the disease, and where isolation will meet with difficulties for many years to come. It is possible that an accurate assessment of the value of B.C.G. in leprosy might be made in Gambia. It is also noteworthy that the incidence of tuberculosis is increasing in Gambia, and B.C.G. introduced for leprosy control might also be of value in the control of tuberculosis.

\section{SUMMARY}

I. A spot survey for leprosy was conducted in the Protectorate of Gambia.

2. Fifteen villages of the predominant tribes in the country were surveyed and the incidence of leprosy was found to vary between $\mathrm{I} \%$ and $3.9 \%$.

3. The overall incidence in the Protectorate was $2.4 \%$.

4. The differences in the incidence of leprosy among the different tribes were not statistically significant.

5. It is suggested that Gambia might be a suitable place to assess the value of B.C.G. in the control of leprosy as:-

(a) Gambia is a small manageable country.

(b) So far there have been few measures taken against leprosy.

(c) There is a high incidence of the disease.

(d) Isolation of infectious cases will meet with considerable opposition.

(e) The incidence of tuberculosis is increasing in Gambia, and B.C.G. measures may also be of value in the control of this disease.

\section{REFERENCE}

Ross, C. M. Report on a Sample Medical Survey of the Gambia in 1947, Government Printer, Bathurst, 1948. 


\section{ACKNOWLEDGMENTS}

We are grateful to the Director of Medical Services, Gambia, who encouraged this investigation; to the Director, Medical Research Council Laboratories, Gambia, for providing facilities; to the Gambia Oil Seeds Marketing Board for kindly providing a launch; to the Senior Commissioner and the Commissioners for help and co-operation; and to Mr. D. P. Gamble for his assistance in the villages.

\section{TABLE 1}

THE INCIDENCE OF LEPROSY IN GAMBIA

Name of Village $\quad$ Tribe $\quad$ Population Cases of leprosy
$\%$

\section{UPPER RIVER DIVISION}

\begin{tabular}{|c|c|c|c|c|c|c|}
\hline Kumbija & $\ldots$ & Serahuli & $\ldots$ & 401 & 14 & 3.5 \\
\hline Kundam group & $\cdots$ & Fula $\ldots$ & $\cdots$ & 439 & 17 & 3.9 \\
\hline Kundam Mandinka & $\ldots$ & Mandinko & $\ldots$ & $37 \mathrm{I}$ & 9 & 2.4 \\
\hline Jam Jam Golie & $\ldots$ & Fula ... & $\ldots$ & 276 & 6 & 2.2 \\
\hline Total number & am & $\ldots$ & $\ldots$ & $I, 487$ & 46 & 3.I \\
\hline
\end{tabular}

MacCarthy Island Division

\begin{tabular}{|c|c|c|c|c|c|c|c|}
\hline Jakhali ... & $\ldots$ & $\ldots$ & Serahuli & $\ldots$ & 324 & 4 & $\mathrm{I} .2$ \\
\hline Baiti Momad & Fana & $\ldots$ & Wollof & $\ldots$ & 608 & r6 & 2.6 \\
\hline Sulkuta $\ldots$ & $\ldots$ & $\cdots$ & Mandinko & $\ldots$ & 421 & 4 & I \\
\hline Chamen & $\ldots$ & $\ldots$ & Fula ... & $\ldots$ & 4 II & 13 & \\
\hline \multicolumn{4}{|c|}{ Total number examined } & $\ldots$ & $\mathrm{r}, 764$ & 37 & \\
\hline
\end{tabular}

\section{Central Division}

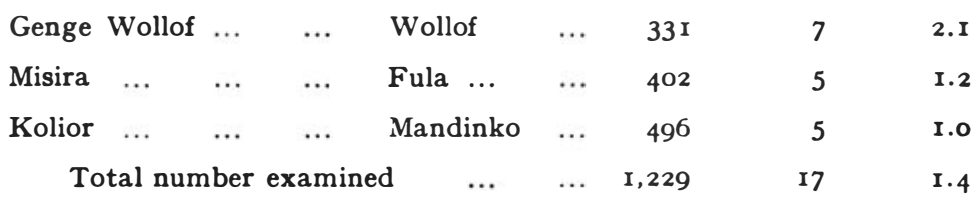

\section{WESTERN Division}

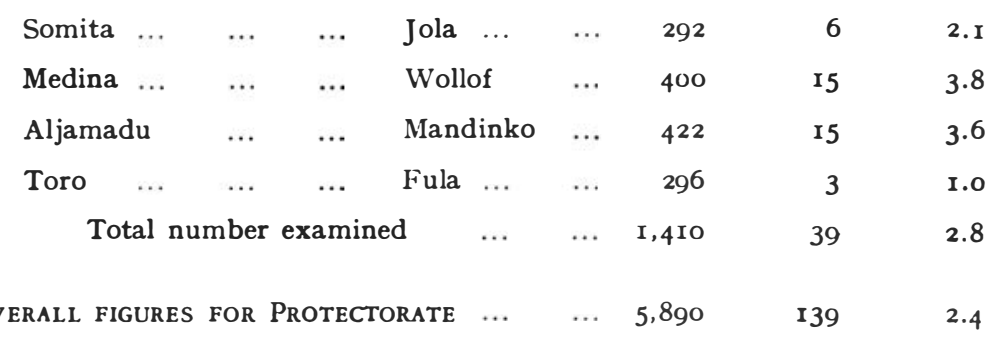


TABLE 2

ANALYSIS OF CASES OF LEPROSY ON CLINICAL GROUNDS

UPPER RIVER DIVISION

Number of cases of leprosy examined $\quad \ldots \quad \ldots \quad \ldots \quad 46$

$\begin{array}{lllllll}\text { Number of tuberculoid cases } \ldots & \ldots & \ldots & \ldots & 26 & 56.5 \%\end{array}$

$\begin{array}{llllll}\text { Number of lepromatous cases } & \ldots & \ldots & \ldots & 15 & 32.6 \%\end{array}$

$\begin{array}{lllllll}\text { Number of doubtful classification } & \ldots & \ldots & \ldots & 5 & 10.9 \%\end{array}$

MacCarthy Island Division

$\begin{array}{lllll}\text { Number of cases of leprosy examined } & \ldots & \ldots & 37\end{array}$

$\begin{array}{lllll}\text { Number of tuberculoid cases } \ldots & \ldots & \ldots & \ldots & 22\end{array}$

$\begin{array}{llll}\cdots & \cdots & \mathrm{I} 4 & 37.8 \%\end{array}$

$\begin{array}{llllll}\text { Number of doubtful classification } & \ldots & \ldots & \ldots & \text { I } & 2.7 \%\end{array}$

\section{Central Division}

Number of cases of leprosy examined $\quad \ldots \quad \ldots \quad \ldots \quad$ I7

$\begin{array}{lllllll}\text { Number of tuberculoid cases } \ldots & \ldots & \ldots & \ldots & \text { I } 4 & 82.4 \%\end{array}$

$\begin{array}{lllllll}\text { Number of lepromatous cases } & \ldots & \ldots & \ldots & 2 & \text { II.8\% }\end{array}$

$\begin{array}{lllllll}\text { Number of doubtful classification } & \ldots & \ldots & \ldots & \text { I } & 5.8 \%\end{array}$

\section{WESTERN DIVISION}

Number of cases of leprosy examined $\quad \ldots \quad \ldots \quad 39$

$\begin{array}{lllllll}\text { Number of tuberculoid cases } \ldots & \ldots & \ldots & \ldots & 27 & 69.2 \%\end{array}$

$\begin{array}{llllll}\text { Number of lepromatous cases } & \ldots & \ldots & \ldots & 6 & 15.4 \%\end{array}$

$\begin{array}{llllll}\text { Number of doubtful classification } & \ldots & \ldots & \ldots & 6 & 15.4 \%\end{array}$

Overall figures for Protectorate

$\begin{array}{lllll}\text { Number of cases of leprosy examined } & \ldots & \ldots & 139\end{array}$

$\begin{array}{lllllll}\text { Number of tuberculoid cases } \ldots & \ldots & \ldots & \ldots & 89 & 64.0 \%\end{array}$

$\begin{array}{llllll}\text { Number of lepromatous cases } & \ldots & \ldots & \ldots & 37 & 26.6 \%\end{array}$

$\begin{array}{llllll}\text { Number of doubtful classification } & \ldots & \ldots & \ldots & 13 & 9.4 \%\end{array}$ 